\title{
RAINWATER MANAGEMENT IN PROTECTED AREAS
}

\author{
Wioletta Żarnowiec', Andrzej Bogdał', Tomasz Kowalik', \\ Włodzimierz Kanownik' ${ }^{1}$ Krzysztof Ostrowski ${ }^{1}$, Włodzimierz Rajda'
}

1 Department of Land Reclamation and Environmental Development, University of Agriculture in Krakow, Al. Mickiewicza 24-28, 30-059 Kraków, Poland, e-mail: wzarnowiec@ur.krakow.pl; rmbogdal@cyf.kr.edu.pl; rmkowali@cyf.kr.edu.pl; rmkanown@cyf-kr.edu.pl; rmostrow@cyf-kr.edu.pl; rmrajda@cyf-kr.edu.pl

Received: 2016.12.24

Accepted: 2017.01.26

Published: 2017.03.01

\begin{abstract}
The aim of the study was to find out whether the climate of southern Poland allows for removing rainwater from industrial areas by evaporation from roof surfaces. The study covered the premises of a Logistics Centre with an approximate area of 34 hectares, located in the catchment of the Wedonka stream and in the region of water intake for Kraków at the Rudawa river. In the future, the Centre will comprise nine large warehouses. Road traffic associated with the project will cause potential risks for groundwater and surface water of this protected area. Therefore, the Centre's investor decided to evaporate rainwater from the premises. To establish advisability of this plan, the study team designed and built a unique experimental station consisting of experimental roof, a tank for collecting water for the sprinkler system, system for delivering, distributing and discharging water from the roof, measuring tilt tray, automatic meteorological station, and electronic devices for recording measurement data. The research on the experimental station was carried out from April to October in 2011 and 2012 and included continuous measurements of the volume of water supplied to and discharged from the roof. Moreover, the temperature of the roof and water in the tank and the number of important meteorological parameters were measured. The difference between supplied and discharged water, divided by the wetted surface of the roof, helped to determine thickness of the evaporation layer in millimeters. The study confirmed the possibility of removing potentially contaminated rainwater by evaporating it from roof surfaces of the Logistics Centre located near Kraków at an average rate of $5.9 \mathrm{dm}^{3} \cdot \mathrm{m}^{-2} \cdot \mathrm{d}^{-1}$. However, due to high seasonal variability of rainfall and air temperature, it is necessary to temporarily collect water in an expansion tank of suitable capacity.
\end{abstract}

Keywords: industrial roof, experimental station, evaporation, rainwater

\section{INTRODUCTION}

Increasing urbanization and development of industrial and communication areas turns natural land into paved or sealed surfaces that significantly alter a rainfall-runoff relationship [Bzymek i Jarosińska 2012, Wałęga et al. 2013] and adversely affect water quality [Bogdał et al. 2012, Hutchins 2012, Mouri et al. 2012, Bakarat et al. 2013, Kanownik et al. 2013, Policht et al. 2014, Bogdał i Kowalik 2015, Bogdał et al. 2016]. Rainwater outflowing from impermeable surfaces is usually collected and discharged into a rainwater drainage system via which it reaches water bodies and watercourses [Burszta-Adamiak 2012, Wałęga et al. 2013].

Economic development often involves conflicts related to investments and their effect on the environment, especially if they are to be located in protected areas, e.g. water intake protection zones. Pursuant to the Water Act, in places where construction of a drainage system would not bring any benefits to the environment or would incur excessive costs, individual systems or other solu- 
tions must be applied to ensure the same level of environmental protection as the drainage system [Ustawa 2001].

In order to protect water intended for human consumption and supplied to plants requiring water of high quality, it is necessary to prevent water pollution and thus minimize the need for its subsequent treatment. One of the methods to ensure adequate water quality is to establish direct and indirect water intake protection zones. In a direct protection zone, it is forbidden to use land for purposes unrelated to water intake. In an indirect protection zone the list of prohibited or restricted activities may include construction works and other works that reduce the usefulness of water or the efficiency of the water intake, such as discharging sewage into watercourses or soil, constructing storage facilities for petroleum products, building parking lots etc. [Ustawa 2001].

In protected areas, an alternative to traditional methods of rainwater management may be evaporation of water into the atmosphere [Żarnowiec 2015]. This is the solution that was opted for in a large-size Logistics Centre located in Modlnicz$\mathrm{ka}$, in the catchment of the Wedonka stream, near Kraków. Road transport of goods to the warehouses associated with this investment may pollute the Wedonka stream whose entire catchment is located in the water intake protection zone. The Wedonka is a left tributary of the Rudawa on which the water intake facility supplying the city of Kraków is located. As the local authorities did not issue a permission to discharge water from the Centre's paved areas into the Wedonka, the investor was forced to seek other achievable and environmentally friendly solutions. They decided to collect water in a local retention reservoir and then sprinkle it onto the roofs of several warehouses in order to evaporate it. To determine advisability of this plan, a unique experimental station was designed and built to measure basic meteorological parameters and water volumes evaporated from a roof with a structure identical to that of the warehouses to be built on the Logistics Centre's premises.

The aim of the study was to determine whether the climate of southern Poland allows for removing rainwater from industrial areas by evaporation from warehouse roofs. The research identified roof surface area necessary to completely evaporate the rainwater. The paper discusses in detail the devices used to build the experimental station and their mode of operation. It also includes a simulation of water management on the
Logistics Centre's premises, prepared on the basis of research conducted between the spring and autumn of 2011 and 2012.

\section{MATERIALS AND METHODS}

The Logistics Centre covering 34 ha is located in Modlniczka, $9.5 \mathrm{~km}$ north-west of the Kraków city center. In the future, its premises will comprise nine large-size warehouses with total surface area of 15.24 ha: warehouse B1 with the area of $12,192 \mathrm{~m}^{2}, \mathrm{~B} 2-22,008 \mathrm{~m}^{2}, \mathrm{~B} 3$ $-13,930 \mathrm{~m}^{2}$, B4 -20,852 $\mathrm{m}^{2}$, B5 - 34,716 $\mathrm{m}^{2}$, B6 - 20,089 $\mathrm{m}^{2}$, B7 - 12,468 $\mathrm{m}^{2}, \mathrm{~B} 8-7,995 \mathrm{~m}^{2}$, and $\mathrm{B} 9-8,150 \mathrm{~m}^{2}$ (Figure 1). In addition, asphalt roads, parking lots and bays will cover the area of $87,256 \mathrm{~m}^{2}$, pavements and sidewalks $-6,296$ $\mathrm{m}^{2}$ and green areas and roadsides $-96,515 \mathrm{~m}^{2}$ [Operat wodno-prawny 2009].

The resulting road transport of goods constitutes potential risk for the Wedonka stream, the catchment of which is located in the intermediate zone of the Rudawa water intake. The Municipal Water Supply and Sewage Company in Kraków granted its consent for the investment in the water intake zone, on condition that the investor ensures appropriate protection of the Wedonka water from pollution. This is why the investor needed to employ this unusual solution aimed at eliminating rainwater outflow from the Logistics Centre's paved transportation surfaces. It consisted in collecting outflowing water in a local retention reservoir and, following rough pretreatment, sprinkling it onto warehouse roofs in periods conductive to evaporation, in order to discharge it into the atmosphere.

This encouraged the Logistics Centre to build a unique research station on its premises in order to determine the actual evaporation from the roof surfaces. The researchers from the Department of Land Reclamation and Environmental Development, University of Agriculture in Kraków designed and supervised the construction of the station and used it to make relevant measurements. It included (Fig. 2) an experimental roof, a tank for collecting water for the sprinkler system, a closed system for supplying, distributing and discharging water from the roof, measuring tilt tray, automatic meteorological station, and electronic devices for recording measurement data.

Roof (Fig. 2) with the surface of $72 \mathrm{~m}^{2}$ $(24 \times 3.0 \mathrm{~m})$ was placed on steel joists that were 


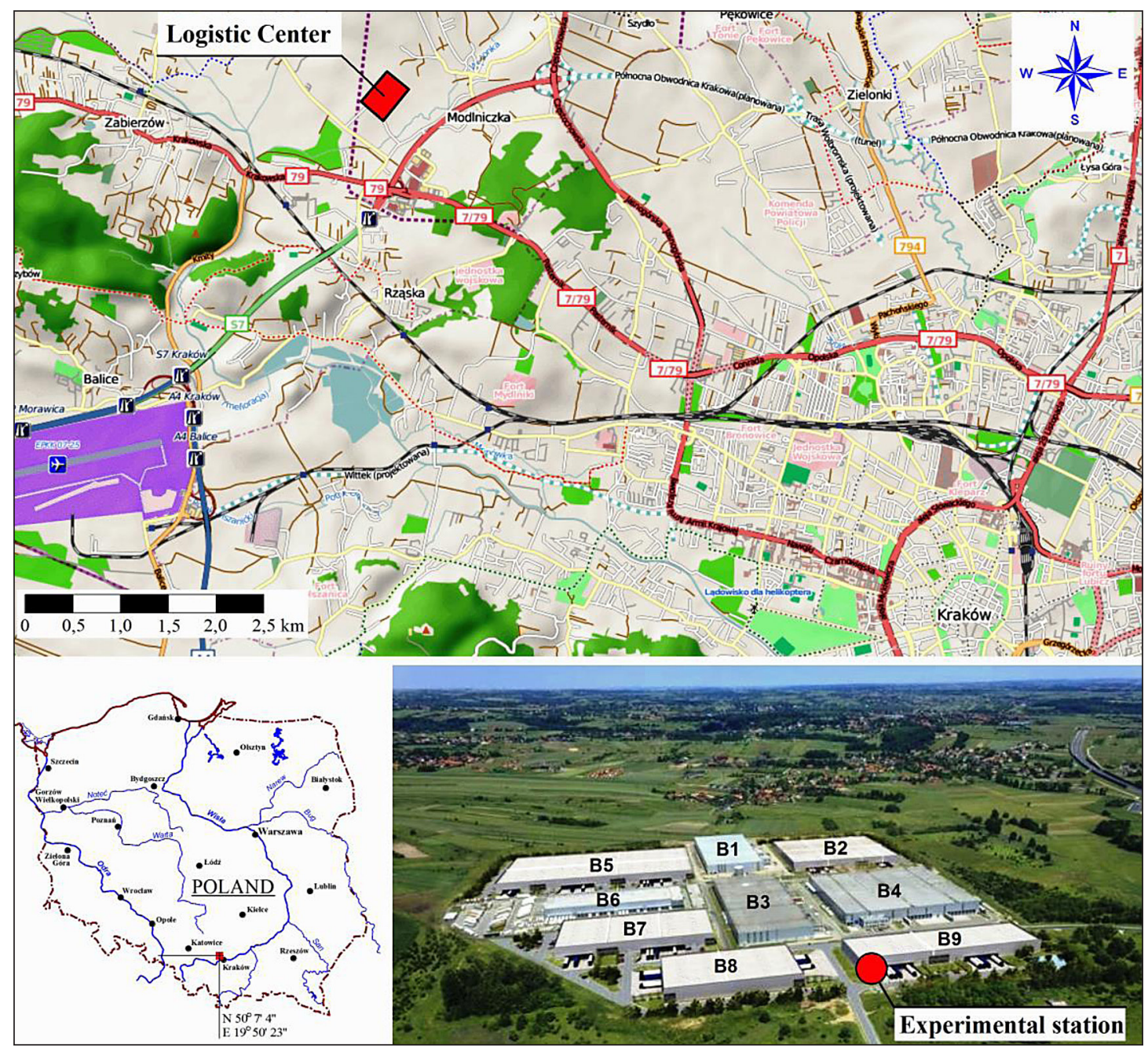

Figure 1. Location of the experimental station

supported by poles at $3.10 \mathrm{~m}$ from the eaves and at $3.58 \mathrm{~m}$ from the opposite side. Its pitch was $2 \%$ and westerly oriented. The roof length, pitch and cover were identical to those of the warehouses to be built at the Logistics Centre. Its surface was lined with $1.5 \mathrm{~mm}$ thick PVC membrane. "PUR" thermal insulation made of foam, vapor barrier film and trapezoidal steel sheet was put under the membrane. To avoid uncontrolled water outflow to the sides and to prevent droplets from drifting during sprinkling, $60 \mathrm{~cm}$ high, transparent plastic covers were mounted at the long edges of the roof.

EKO-SUM tank (Fig. 2) was placed under the higher part of the experimental roof. It was used to collect water discharged from the roof to be reused for further sprinkling. It was $266 \mathrm{~cm}$ long, had an elliptical cross-section (vertical diameter of $160 \mathrm{~cm}$ and horizontal diameter of $170 \mathrm{~cm}$ ) and was equipped with a storm overflow and bottom drain with a manual valve. Inside the tank, a water level sensor was mounted capable of shut- ting down the hydrophore automatically when the amount of water decreased to the level threatening with an air-lock. The tank included also a hydrophore strainer and a temperature sensor. Minimum capacity of the tank accounted for the roof outflow $\left(\mathrm{Q}_{\mathrm{d}}\right)$ during reliable rainfall:

$$
\begin{gathered}
\mathrm{Q}_{\mathrm{d}}=\Psi \cdot \frac{\mathrm{q}}{10000} \cdot \mathrm{F}_{\mathrm{d}}\left[\mathrm{dm}^{3} \cdot \mathrm{s}^{-1}\right] \\
\mathrm{Q}_{\mathrm{d}}=0.95 \cdot \frac{166}{10000} \cdot 72=1.135 \mathrm{dm}^{3} \cdot \mathrm{s}^{-1}
\end{gathered}
$$

where: $\Psi=0.95$ - roof runoff coefficient [Wałęga 2013],

$q=\mathrm{A} \cdot \mathrm{t}^{0.667}=1013 \cdot 15^{0.667}=166 \mathrm{dm}^{3} \cdot \mathrm{s}^{-1}$ $\cdot$ ha $^{-1}-$ specific outflow,

$A=1013$ - for average annual rainfall at the meteorological station in Kraków and rainfall intensity, with probability $\mathrm{p}$ and duration $\mathrm{t}=15$ minutes,

$F_{d}=72 \mathrm{~m}^{2}-$ experimental roof surface. 

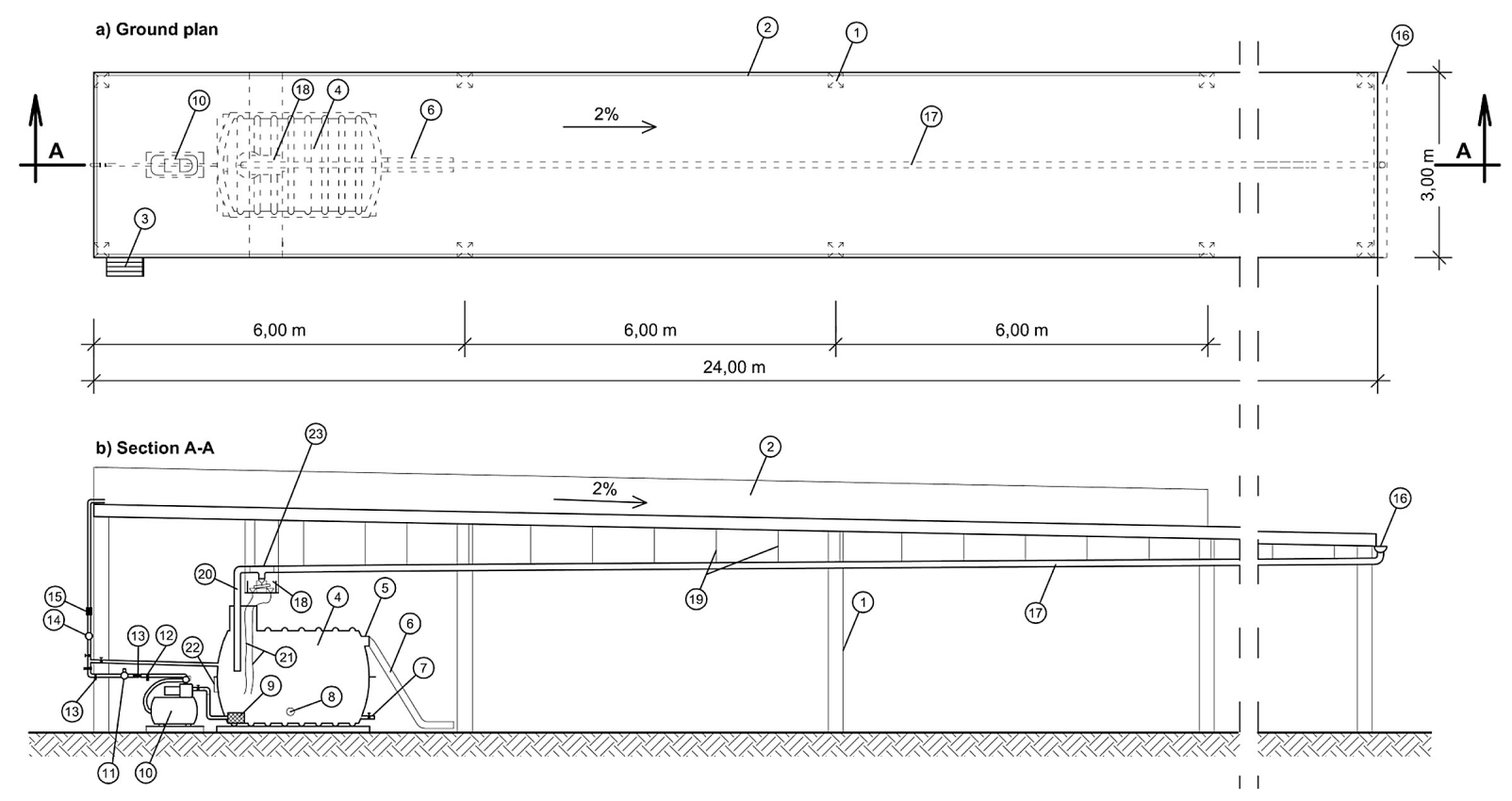

Figure 2. Scheme of experimental station: 1 - steel poles, 2 - side shielding of the roof, 3 - ladder, 4 - tank for gathering water, 5 - emergency outflow (storm drain), 6 - tube draining excess water, 7 - tank draining trigger, 8 - sensor (pressure) of water level in the tank, 9 - hydrophore strainer, 10 - hydrophore, 11 - pressure regulator, 12 - mesh filter, 13 - disc filter, 14 - flow meter, 15 - electrovalve, 16 - gutter, 17 - gravity pipeline draining the water from the roof, 18 - measuring tilt tray, 19 - rigid beams, 20 - emergency spillway to the tank, 21 - elastic hoses, 22 - device registering inflow and outflow from the roof, 23 - tee

Minimum capacity of the tank designed to accommodate water from such rainfall was:

$$
\begin{gathered}
\mathrm{V}_{\mathrm{zb}}=\mathrm{Q}_{\mathrm{d}} \cdot \mathrm{t}\left[\mathrm{m}^{3}\right] \\
\mathrm{V}_{\mathrm{zb}}=1.135 \mathrm{dm}^{3} \cdot \mathrm{s}^{-1} \cdot 15 \mathrm{~min} \cdot 60 \mathrm{~s} \\
=1021 \mathrm{dm}^{3}=1.021 \mathrm{~m}^{3}
\end{gathered}
$$

In order to accommodate volumes greater than those resulting from reliable rain or longterm rainfall with high total volume, and to secure water supply for sprinkling the roof during rainless periods and/or on days with intensive evaporation, the tank capacity was increased to $4 \mathrm{~m}^{3}$. This provided room for water discharged from the roof for the rainfall of $56 \mathrm{~mm}$, which in an average year is half of the total rainfall in July in Kraków.

System supplying water onto the roof (Fig. 2) ensured proper operating conditions for sprinkling equipment. Water from the tank was transported to micro-sprinklers via a hydrophore and a $3 / 4$ " diameter pipeline, on which a pressure regulator was installed to control sprinkling efficiency and working field. In addition, the pipeline was equipped with a 120 mesh filter, disc filter, flow meter, and electrovalve controlled by a sensor located in a rain gauge included in the meteorological station. The electrovalve was designed to turn off the water supply onto the roof at any time rain- fall occurred. The volumes of water supplied onto the roof, determined automatically in $\mathrm{dm}^{3}$ on the basis of impulses transmitted from the flow meter ( 1 pulse $\left.=0.25 \mathrm{dm}^{3}\right)$, were stored in memory of $\mathrm{R} 2$ recorder at 30-minute intervals.

Water distribution system (Fig. 2 and 3) was mounted along the long side of the roof in the form of a distributing pipeline (PCV, $3 / 4$ " diameter, $17 \mathrm{~m}$ long). In order to effectively wet as large part of the roof surface as possible, 11 pipes $(1 / 2$ " diameter, closed manually, spaced every $1.5 \mathrm{~m}$ ) were connected to the pipeline. At the end of the pipes connections for sprinkling equipment were installed that offered two options of roof wetting (micro-sprinklers or drippers) in order to achieve desired evaporation effect. 08 PE TANAKE micro-sprinklers with $0.8 \mathrm{~mm}$ diameter nozzle were used. Their performance at the optimum pressure of $\mathrm{H}_{\mathrm{z}}=1.0 \mathrm{~atm}$ was $\mathrm{q}_{\mathrm{z}}=0.023 \mathrm{~m}^{3} \cdot \mathrm{h}^{-1}$, and the radius of wetting reached $\mathrm{R}=1.8 \mathrm{~m}$. The required number of simultaneously active sprinklers was determined on the basis of average evaporation of free water levels on sunny summer days in Kraków $\left(0.417 \mathrm{~mm} \cdot \mathrm{h}^{-1}\right)$. It was tentatively assumed that around noon, on days with low air humidity, evaporation may be even three times higher, i.e. $1.25 \mathrm{~mm} \cdot \mathrm{h}^{-1}$. This corresponded to the supply onto the experimental roof equal to $\mathrm{Q}_{\mathrm{z}}=$ 


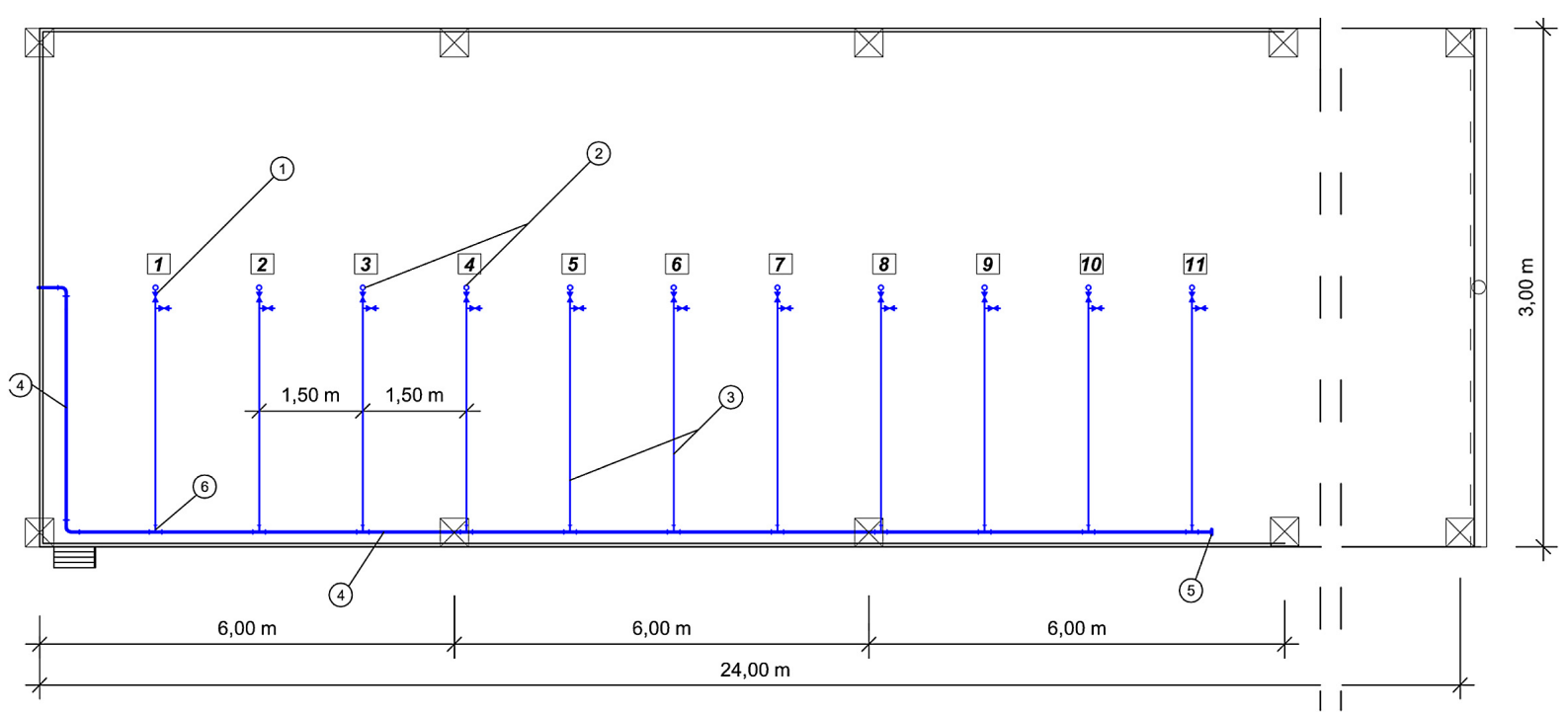

Figure 3. Sprinkler system on the experimental roof: 1 - manual valve, 2 - micro sprinkler terminal, 3 - irrigation pipe system, 4 - distribution pipe system, 5 - pipe cap, 6 - T-connector, $1-11$ - sprinklers stands

$0.090 \mathrm{~m}^{3} \cdot \mathrm{h}^{-1}\left(72 \mathrm{~m}^{2} \cdot 0.00125 \mathrm{~m}^{3} \cdot \mathrm{h}^{-1}\right)$, which required 4 micro-sprinklers with catalog parameters $\left(Q_{\mathrm{z}}: \mathrm{q}_{\mathrm{mz}}=0.090: 0.023=4\right)$ to work simultaneously. In the course of the study, the above theoretical assumptions were adjusted, as it turned out that six sprinklers operating simultaneously provided better effects and facilitated wetting a larger area of the roof.

System discharging water from the roof (Fig. 2) consisted of a gutter collecting water from the roof surface, and a gravity pipeline (PVC, 80 $\mathrm{mm}$ diameter, $4 \%$ pitch) discharging water to a chamber of the measuring tilt tray. During rainfall, part of the outflow was delivered directly into the tank, depending on its intensity. Filling levels of the discharging pipeline $\left(\mathrm{h}_{\mathrm{z}}\right)$, at the flow of $\mathrm{Q}_{\mathrm{z}}=$ $0.025 \mathrm{dm}^{3} \cdot \mathrm{s}^{-1}$ generated during spraying the roof, and filling levels at flow $Q_{d}=1.135 \mathrm{dm}^{3} \cdot \mathrm{s}^{-1}$ occurring during natural rainfall with probability $\mathrm{p}$ $=10 \%$ and duration $\mathrm{t}=15 \mathrm{~min}$, were established based on a consumption curve. When calculating the filling levels essential for the operation of the measuring tilt tray, geometrical parameters of the pipeline section, roughness factor and generally known hydraulic formulas for pressureless flow were all taken into account. The calculations are summarized in Table 1. The calculated filling levels in the discharging pipeline $h_{z}$ during spraying of the roof amounted to $0.75 \mathrm{~cm}$ (Table 1). Then, the entire $Q_{h}$ flow entered the measuring tray chamber via a tee branch and a calibrated hole in its cap. This was possible because a narrower branch of the $80 / 50 \mathrm{~mm}$ tee mounted on the discharging pipeline was connected to a wider tee branch at the height of $\mathrm{h}_{3}=1.0 \mathrm{~cm}$ from the bottom of the discharging pipe - i.e. over the filling level $h_{z}$. However, during reliable rainfall that generated outflow $Q_{d}$, the filling level in the pipeline was $4.5 \mathrm{~cm}$ (Table 1). In these periods, the measuring tray chambers received much more water than $Q_{z}$ (increased levels in the tee), but the signal from the rainfall sensor closed the electrovalve on the pipeline supplying water to the roof, and the flow in the discharging pipeline was not recorded. Its full amount was directed into the tank, both through the main pipeline and chambers of the measuring tilt trays (Fig. 2).

Device for measuring water outflow from the roof consisted of a tilt tray with two chambers mounted over the tank inlet (Fig. 2). The tray was made from a section of a PVC pipe with an oblong hole cut in its central upper wall along a line parallel to the tray axis. This secured free flow of water from the pipeline to the tray chambers, through a funnel mounted below the tee branch of the discharging pipeline. Capacity of a single chamber was $250 \mathrm{~cm}^{3}$, which allowed for a sufficiently accurate measurement of the outflow in the predefined 30-minute intervals. Information about the total number of discharges from the chambers, and thus the volume of outflow from the roof, was stored in the memory of a R2 recorder. Water needed approximately 8 seconds to fill the chamber and when the outflow was smaller (higher evaporation) the time was proportionally longer. The water from the tray flowed into the tank through funnels and flexible pipes reaching its bottom. This was to eliminate the ripple of 
Table 1. Hydraulic parameters of the discharging pipeline

\begin{tabular}{|c|c|c|c|c|c|c|c|c|c|}
\hline $\begin{array}{c}\mathrm{h}_{\mathrm{z}} \\
{[\mathrm{cm}]}\end{array}$ & $\begin{array}{l}\Theta_{h} \\
{\left[{ }^{\circ}\right]}\end{array}$ & $\begin{array}{c}\mathrm{F}_{\mathrm{h}} \\
{\left[\mathrm{cm}^{2}\right]}\end{array}$ & $\begin{array}{c}\mathrm{d}_{\mathrm{h}} \\
{[\mathrm{cm}]}\end{array}$ & $\begin{array}{c}R_{h} \\
{[\mathrm{~m}]} \\
\end{array}$ & $\begin{array}{c}1 \\
{[\%]}\end{array}$ & $\begin{array}{c}\gamma \\
{[-]}\end{array}$ & $\begin{array}{l}C_{h} \\
{[-]}\end{array}$ & $\begin{array}{c}\mathrm{V}_{\mathrm{h}} \\
{\left[\mathrm{m} \cdot \mathrm{s}^{-1}\right]}\end{array}$ & $\begin{array}{c}Q_{\mathrm{h}} \\
{\left[\mathrm{dm}^{3} \cdot \mathrm{s}^{-1}\right]}\end{array}$ \\
\hline 0.5 & 58 & 1.31 & 4.05 & 0.0032 & \multirow{8}{*}{0.4} & \multirow{8}{*}{0.2} & 22.0 & 0.079 & 0.010 \\
\hline $0.75^{1)}$ & 71 & 2.35 & 4.96 & 0.0047 & & & 25.53 & 0.111 & $0.026^{1)}$ \\
\hline 1.0 & 83 & 3.65 & 5.79 & 0.0063 & & & 28.4 & 0.143 & 0.052 \\
\hline 2.0 & 120 & 9.83 & 8.38 & 0.0117 & & & 35.1 & 0.240 & 0.236 \\
\hline 3.0 & 151 & 17.21 & 10.54 & 0.0163 & & & 39.0 & 0.315 & 0.542 \\
\hline 4.0 & 180 & 25.13 & 12.57 & 0.0200 & & & 41.4 & 0.370 & 0.930 \\
\hline $4.5^{2)}$ & 194 & 29.02 & 13.54 & 0.0214 & & & 42.2 & 0.390 & $1.132^{2)}$ \\
\hline 4.6 & 197 & 29.85 & 13.75 & 0.0217 & & & 42.4 & 0.395 & 1.179 \\
\hline
\end{tabular}

$\mathrm{h}_{\mathrm{z}}$ - filling levels in the pipe; $\Theta_{\mathrm{h}}$ - angle of a circular segment of cross-section; $\mathrm{F}_{\mathrm{h}}$ - cross-section active area;

$\mathrm{d}_{\mathrm{h}}$ - wetted perimeter; $\mathrm{R}_{\mathrm{h}}$ - hydraulic radius; $\mathrm{I}$ - hydraulic gradient; $\gamma$ - roughness coefficient;

$\mathrm{C}_{\mathrm{h}}$ - velocity coefficient; $\mathrm{V}_{\mathrm{h}}$ - water velocity by Cheze; $\mathrm{Q}_{\mathrm{h}}-$ flow

1) for filling the pipeline while spraying the roof

${ }^{2)}$ for filling the pipeline during rainfall with probability $\mathrm{p}=10 \%$ and duration $\mathrm{t}=15 \mathrm{~min}$.

water in the tank and ensure the measurement of filling levels with the pressure sensor.

"DAVIS Vantage PRO2", an automatic meteorological station, was placed next to the experimental roof and equipped with a thermometer, ombrometer, hygrometer, anemometer, pyranometer, and transmitters communicating radio signals to the R1 recorder. The station was programmed to sample data at 15 -second intervals; the recorder stored total and average meteorological parameters in its memory.

Electronic devices for continuous monitoring and recording of data were deployed in two places. The first one (R1) was placed in the Logistics Centre's administrative building, approximately $20 \mathrm{~m}$ from the meteorological station. It collected data sent wirelessly from the station and from sensors $\mathrm{C}_{1}$ and $\mathrm{C}_{2}$ that measured the temperature of the roof and of the water in the tank, respectively. The second one (R2), mounted on the tank front wall, collected data transmitted by wire on the inflow and outflow from the roof. Additionally, it received data from the water level sensor mounted on the tank $\left(\mathrm{C}_{3}\right)$ and information from the meteorological station about the occurrence of rainfall.

From April to October 2011 and 2012, the study team investigated the dynamics of water evaporation from the experimental roof. The volume of water supplied to and discharged from the roof was measured continuously along with a number of major meteorological parameters. Moreover, the area wetted by six micro-sprinklers installed on the experimental roof was assessed on weekly basis. The difference between the water supplied to and discharged from the roof, divided by average values obtained from two consecutive periods in which the measurements of the wetted area were taken, was computed to determine the thickness of the evaporation layer in millimeters. The recorded and calculated hydrological and meteorological parameters were the basis for determining their total values in any period of time. Basic statistics describing total daily evaporation volumes during the research period were computed based on the empirical data.

The volume of surface outflow from the partial surfaces on the Logistics Centre's premises for both 7-month research periods was calculated from the following formula:

$$
\mathrm{V}_{\mathrm{i}}=0.001 \cdot \mathrm{P} \cdot \Psi_{\mathrm{i}} \cdot \mathrm{F}_{\mathrm{i}}\left[\mathrm{m}^{3}\right]
$$

where: $P-$ total rainfall in the investigated period $[\mathrm{mm}]$; data from the study meteorological station,

$\Psi_{i}$ - surface runoff coefficient [-] for given $i$ of the Logistics Centre's partial surface area; coefficient depending on type of surface [Wałęga et al. 2013], $F_{i}$ - surface area of the Logistics Centre's partial surface area $i\left[\mathrm{~m}^{2}\right]$.

A simulation of rainwater management on the Logistics Centre's premises was performed in two scenarios. In the first one, it was assumed that water flowing from the entire area (over $34 \mathrm{ha}$ ) into the retention reservoir might be evaporated from the roofs of all the warehouses of total surface area $152,400 \mathrm{~m}^{2}$. The second scenario was based on the assumptions of the Water Quality Impact Assessment [Operat wodno-prawny 2009] that clean outflow from the roofs of warehouses B1, B5, B6 and B7 would be discharged into the We- 
donka stream, and the outflow from warehouse B2 and 9,000 $\mathrm{m}^{2}$ green area would be discharged into trench $\mathrm{C}$. The remaining water would be sprinkled onto the roofs of buildings B3, B4, B8 and B9, with a total surface area of $50,927 \mathrm{~m}^{2}$.

\section{ANALYSIS OF RESULTS}

Pluviothermal conditions in individual months of the research period, assessed according to Kaczorowska [1962] and Ziernicka [2001], varied considerably. A particularly large variation occurred in 2011, with extremely dry September, very dry June, dry May and October, average August, wet April and very wet July. Year 2012 was much less eventful, as only three out of seven rainfall features were observed: May was very dry, August and September were dry, and the other months were average. In contrast, 2012 was more varied in terms of temperature: July was extremely warm, May and August very warm, June and September normal, and April and October cold. In 2011, three types of months occurred: very warm April and August, cold September and the remaining 4 months had air temperature close to the average recorded for the multi-annual period of 1971-2000.

In such variable weather conditions, total evaporation from the experimental roof, recorded for individual months, varied heavily. The greatest evaporation, exceeding $200 \mathrm{~mm}$, was recorded in June $2011(219 \mathrm{~mm})$, and in July and August 2012 (207 and $221 \mathrm{~mm}$, respectively). The smallest total monthly evaporation of only $44 \mathrm{~mm}$ was observed in unusually cold October 2011. On average, in both 7-month research periods $1,077 \mathrm{~mm}$ layer of water was evaporated. The process was more effective in 2012 when $15 \%$ more water changed its state from liquid into gas (Table 2).

Mean daily volume of water evaporated from $1 \mathrm{~m}^{2}$ of the wetted surface in the years 2011-2012 was $5.9 \mathrm{dm}^{3}$. It can be stated with $95 \%$ certainty that the actual average daily evaporation ranged between 5.6-6.1 mm. Maximum daily evaporation of $12.9 \mathrm{~mm}$ was recorded on 27 June 2012, and minimum daily evaporation $(0.9 \mathrm{~mm})$ occurred twice: on 7 October 2011 and 7 October 2012. The values of variability measures, i.e. coefficient of variation and standard deviation, indicated average variation of daily evaporation in the years 2011 and 2012 (Table 3).

The volume of water discharged from the Logistics Centre's entire area (34.2 ha), simulated based on rainfall totals and taking into account varied surface runoff coefficients [Wałęga et al. 2013] during the 7-month periods of 2011 and 2012 was 89.25 and 74.57 thousand $\mathrm{m}^{3}$, respectively (Table 4) - an average of 82 thousand $\mathrm{m}^{3}$. If only the area of the Logistics Centre (23.2 ha) from which discharged water was to be evaporated in Scenario II was considered, the expected volumes in the consecutive years amounted to 52.57 and 43.93 thousand $\mathrm{m}^{3}$, respectively (Tab. 4) - an average of 48.25 thousand $\mathrm{m}^{3}$.

During the seven months of 2011, the water discharged from the Logistics Centre's entire premises (Scenario I) could be evaporated using $58.5 \%$ the surface of all warehouses roofs, whereas in 2012 , as little as $42.5 \%$ of this surface would suffice for this purpose (Table 5). Therefore, it may be concluded that the total surface area of the Logistics Centre's warehouse roofs available for evaporation of rainwater outflow is much larger

Table 2. Monthly totals of evaporation (mm) from the experimental roof in 2011 and 2012

\begin{tabular}{|c|c|c|c|c|c|c|c|c|}
\hline \multirow{2}{*}{ Year } & \multicolumn{9}{|c|}{ Month [mm] } & \multicolumn{4}{c|}{$\Sigma$ IV-X } \\
\cline { 2 - 10 } & IV & V & VI & VII & VIII & IX & X \\
\hline 2011 & 100 & 179 & 219 & 168 & 144 & 148 & 44 & 1002 \\
\hline 2012 & 82 & 184 & 189 & 207 & 221 & 187 & 81 & 1151 \\
\hline Average & 91 & 182 & 204 & 188 & 183 & 168 & 63 & 1077 \\
\hline
\end{tabular}

Table 3. Selected descriptive statistics of daily evaporation totals during the research period of 2011- 2012

\begin{tabular}{|c|c|c|c|c|c|c|}
\hline \multicolumn{2}{|c|}{ Range of values } & \multirow{2}{*}{ Average } & \multicolumn{2}{|c|}{$\begin{array}{c}\text { The confidence interval of average } \\
\text { at } 95 \%\end{array}$} & \multirow{2}{*}{ Standard deviation } & \multirow{2}{*}{$\begin{array}{l}\text { Coefficient } \\
\text { of variations }\end{array}$} \\
\hline $\begin{array}{l}\text { Minimum } \\
\text { value }\end{array}$ & $\begin{array}{l}\text { Maximum } \\
\text { value }\end{array}$ & & $-95 \%$ & $+95 \%$ & & \\
\hline $0.9 \mathrm{~mm}$ & $12.9 \mathrm{~mm}$ & $5.9 \mathrm{~mm}$ & $5.6 \mathrm{~mm}$ & $6.1 \mathrm{~mm}$ & $2.3 \mathrm{~mm}$ & $39.3 \%$ \\
\hline
\end{tabular}


Table 4. Simulated surface runoff from the Center premises in 2011 and 2012

\begin{tabular}{|c|c|c|c|c|c|c|}
\hline \multicolumn{2}{|c|}{ Center premises } & \multirow{2}{*}{$\begin{array}{c}\text { Runoff } \\
\text { coefficients } \\
\Psi_{i}[-]\end{array}$} & \multicolumn{2}{|c|}{$\begin{array}{c}\text { Rainfall }[\mathrm{mm}] \\
\text { during the period }\end{array}$} & \multicolumn{2}{|c|}{$\begin{array}{l}\text { Discharge volume } \mathrm{Vi}\left[\mathrm{m}^{3}\right] \\
\text { during the period }\end{array}$} \\
\hline Type of surface & $\begin{array}{c}\text { Surface area } \\
\mathrm{F}_{\mathrm{i}}\left[\mathrm{m}^{2}\right]\end{array}$ & & $\begin{array}{l}09 \text { IV }-13 X \\
2011\end{array}$ & $\begin{array}{l}14 \text { IV }-18 X \\
2012\end{array}$ & $\begin{array}{c}09 \text { IV-13 X } \\
2011\end{array}$ & $\begin{array}{c}14 \text { IV-18 X } \\
2012\end{array}$ \\
\hline \multicolumn{7}{|c|}{ Scenario I - discharge from the Logistics Centre's entire premises } \\
\hline Roofs of warehouses & 152400 & 0.95 & \multirow{5}{*}{377} & \multirow{5}{*}{315} & 54582 & 45606 \\
\hline $\begin{array}{l}\text { Asphalt roads, parking } \\
\text { lots, bays }\end{array}$ & 87256 & 0.90 & & & 29606 & 24737 \\
\hline Pavements, sidewalks & 6296 & 0.60 & & & 1424 & 1190 \\
\hline $\begin{array}{l}\text { Green areas, including } \\
\text { roadsides }\end{array}$ & 96515 & 0.10 & & & 3639 & 3040 \\
\hline Total & 341467 & - & & & 89251 & 74573 \\
\hline \multicolumn{7}{|c|}{ Scenario II - discharge from part of the Logistics Centre's premises } \\
\hline Roofs of warehouses & 50927 & 0.95 & \multirow{5}{*}{377} & \multirow{5}{*}{315} & 18240 & 15240 \\
\hline $\begin{array}{l}\text { Asphalt roads, parking } \\
\text { lots, bays }\end{array}$ & 87256 & 0.90 & & & 29606 & 24737 \\
\hline Pavements, sidewalks & 6296 & 0.60 & & & 1424 & 1190 \\
\hline $\begin{array}{l}\text { Green areas, including } \\
\text { roadsides }\end{array}$ & 87515 & 0.10 & & & 3299 & 2757 \\
\hline Total & 231994 & - & & & 52569 & 43934 \\
\hline
\end{tabular}

Table 5. Surface area of warehouse roofs necessary to evaporate water from the Logistics Centre's premises

\begin{tabular}{|c|c|c|c|c|c|}
\hline Wariant & $\begin{array}{c}\text { Measurement } \\
\text { period }\end{array}$ & $\begin{array}{c}\text { Specific } \\
\text { evaporation } \\
{\left[\mathrm{m}^{3} \cdot \mathrm{m}^{-2}\right]}\end{array}$ & $\begin{array}{c}\text { Total discharge } \\
\mathrm{V}\left[\mathrm{m}^{3}\right]\end{array}$ & $\begin{array}{c}\text { Roof surface required } \\
\text { for sprinkling }\left[\mathrm{m}^{2}\right]\end{array}$ & $\begin{array}{c}\text { Utilization of roof } \\
\text { surfaces allocated } \\
\text { for spraying [\%] }\end{array}$ \\
\hline I & \multirow{2}{*}{$\begin{array}{c}\text { 09 IV-13X X } \\
2011\end{array}$} & 1.002 & 89251 & 89072 & 58.5 \\
\cline { 1 - 4 } II & \multirow{2}{*}{$\begin{array}{c}\text { 14 IV-18 X } \\
\text { I }\end{array}$} & 1.151 & 52569 & 52464 & 103.2 \\
\cline { 1 - 4 } II & 2012 & 74573 & 64790 & 42.5 \\
\hline
\end{tabular}

than required. It is thus possible to evaporate entire rainwater in this scenario, provided sufficient roof surface is equipped with sprinkling devices.

In scenario II that assumes rainwater outflow from only part of the Logistics Centre's premises and sprinkling it on four warehouse roofs, all the collected water $(315 \mathrm{~mm})$ could be evaporated in less wet study period of 2011, using $38,170 \mathrm{~m}^{2}$ of the roof surface, i.e. $75 \%$ of the surface allocated for this purpose. However, total rainfall recorded in the 7-month period of 2012, i.e. $377 \mathrm{~mm}$, could not be fully evaporated from the allocated sprinkling area $\left(50,927 \mathrm{~m}^{2}\right)$, as it would require $103.2 \%$ of the available roof surface (Tab. 4 and 5). For these reasons, the surface area to be allocated for evaporation should be increased by an additional roof. It should be also noted that the retention reservoir requires a capacity that is capable of accommodating sufficient surge volumes and outflow surplus in spring and autumn, during winter months which are not conducive to evaporation, and during rainfall.

\section{CONCLUSIONS}

The study results allowed for drawing the following conclusions:

1. In the 7-month research period, mean total evaporation from the roofs was $1,077 \mathrm{~mm}$ and exceeded over threefold the rainfall volume (346 mm), which means that evaporation is a suitable method for rainwater management in protected areas.

2. Climatic conditions in the Kraków area allow for the removal of potentially contaminated rainfall water in protected zones by evaporating it from roof surfaces at an average rate of $5.9 \mathrm{dm}^{3} \cdot \mathrm{m}^{-2} \cdot \mathrm{d}^{-1}$.

3. Given the uneven distribution of rainfall during the year and the inability to evaporate the collected water during periods of low evaporation, or during rainfall, it is necessary to temporarily store water in local retention reservoirs with suitable capacity.

4. Assessment of roof surface area necessary to evaporate total outflow from given premises 
requires simulation calculations of outflows from specific types of surface. It is also necessary to investigate evaporation from a roof surface that depends not only on the regional climate but also on roof parameters, i.e. its pitch, as well as type and color of the covering.

\section{REFERENCES}

1. Bakarat A., El Baghdadi M., Meddah R., Rais J., Nadem S., Afdali M. 2013. Evaluation of water quality in open channels flowing through BeniMellal City (Morocco). J. Water Land Dev., 19 (VII-XII), 3-11.

2. Bogdał A., Kowalik T. 2015. Variability of values of physicochemical water quality indices along the length of the Iwoniczanka stream. Journal of Ecological Engineering, 16 (5), 168-175.

3. Bogdał A., Kowalik T., Kanownik W., Ostrowski K., Wiśnios M. 2012. Ocena stanu fizykochemicznego wód opadowych i odpływających ze zlewni potoku Wolninka. Gaz, Woda i Tech. Sanit., 8, 362-365.

4. Bogdał A., Kowalik T., Ostrowski K., Skowron P. 2016. Seasonal variability of physicochemical parameters of water quality on length of Uszwica river. Journal of Ecological Engineering, 17(1), 161-170.

5. Burszta-Adamiak E. 2012. Wody opadowe w miastach. Rynek Instalacyjny, 5, 35.

6. Bzymek B., Jarosińska E. Wpływ uszczelnienia powierzchni zlewni na odpływ wód deszczowych. Czasopismo Techniczne. Środowisko, 1-Ś/2012 (4), 41-57.

7. Hutchins M.G. 2012. What impact might mitigation of diffuse nitrate pollution have on river water quality in a rural catchment? Journal of Environmental Management, 109, 19-26.

8. Kaczorowska Z. 1962. Opady w Polsce w przekroju wieloletnim. Prace Geogr., IG PAN, $33,1-112$.

9. Kanownik W., Kowalik T., Bogdał A., Ostrowski K. 2013. Quality categories of stream water included in a small retention program. Pol. J. Environ. Stud., 22, 1, 159-165.

10. Mouri G., Shinoda S., Oki T. 2012. Assessing environmental improvement options from a water quality perspective for an urbane rural catchment. Environmental Modelling \& Software, 32, 16-26.

11. Operat wodno-prawny gospodarki wodnej na terenie Centrum Logistycznym Cracow Aiport Logistics Centre Modlniczka, Gmina Wielka Wieś, powiat krakowski. 2009. Maszynopis, BIPROWUMET Sp. z o.o.

12. Policht-Latawiec A., Bogdał A., Kanownik W., Kowalik T., Ostrowski K., Gryboś P. 2014. Jakość i walory użytkowe wody małej rzeki fliszowej. Annual Set The Environment Protection - Rocznik Ochrony Środowiska, 16, 546-561.

13. Ustawa $z$ dnia 18.07.2001 r. Prawo wodne (tekst jednolity z późn. zm.). Dz. U. z 2001 r. Nr 115, poz. 1229.

14. Wałęga A., Radecki-Pawlik A., Kaczor G. 2013. Naturalne sposoby zagospodarowania wód opadowych. Wyd. UR w Krakowie, pp. 235.

15. Ziernicka A. 2001. Klasyfikacja odchyleń od normy temperatury powietrza W Polsce południowowschodniej. Zesz. Nauk. AR w Krakowie, ser. Inż. Środ., 390, 27, 7-18.

16. Żarnowiec W. 2015. Parowanie wody ze zraszanego dachu budynku przemysłowego. Acta Sci. Pol., Formatio Circumiectus, 14(2), 243-251. 